\title{
DEEDS SPEAK LOUDER THAN LOOKS: PINDAR'S ISTHMIAN 4
}

\author{
J du P Boeke (University of Stellenbosch)
}

\begin{abstract}
In the aristocratic milieu of the Panhellenic games beauty was regarded as an outward manifestation of the ability to perform noble deeds. This connection is made explicit in several of Pindar's odes to victors in the combat sports, e.g. in Olympian 8.19, where it is said of the boy wrestler Alkimedon that "he was beautiful to look at, and with his efforts did not dishonour his appearance". Against this background the unflattering remarks about the appearance of Melissos of Thebes in Isthmian 4 come as a surprise. Why does Pindar find it necessary to refer to his unimposing physique when his succes in the games has provided plenty of material for praise? If one considers the norm for the appearance of combat sports athletes as portrayed in the odes, there seems to have been contempt rather than admiration for the victory of an apparently ugly little man. It is proposed that one of the objects of the poem is to defend Melissos against these perceptions and show that he is a worthy winner. Pindar uses several strategies to achieve this. As Homer restored Aias' honour after his suicide by immortalising his noble deeds, so Pindar hopes to light an unquenchable fire of hymns for Melissos and cover him in "delightful grace". He can do this because Melissos shows that deeds determine the worth of a man, not appearance.
\end{abstract}

The commission to commemorate the pancratium victory of Melissos of Thebes in the Isthmian games must have confronted Pindar with one of the more formidable challenges of his career. From Isthmian 4 it appears that the fame of Melissos' family, the Kleonymidai, as warriors and as horse breeders, had suffered in recent times. Four men were lost in battle on one day (Isthm. 4.16-17b), and although they had been successful in chariot races at local games, at the Panhellenic games they had to be satisfied with the rewards of taking part (2530). Indeed, their $\varphi \alpha ́ \mu \alpha \pi \alpha \lambda \alpha i \alpha$ ("ancient fame") "had fallen asleep" (દ่v ü $\pi v \omega \ldots \pi \varepsilon \dot{\varepsilon} \sigma \varepsilon v, 23$ ). As for Melissos himself, he is described in uniquely unflattering terms as not having the

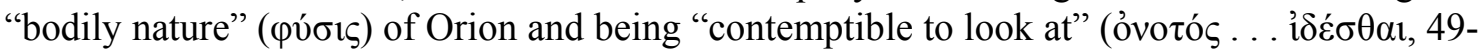
50). In spite of his Panhellenic success he seems to have enjoyed less than universal admiration, since he did not conform to the aristocratic notion of a well-built, beautiful victor.

Pindar's response to the problem posed by the family's decline has received attention in detailed treatments of the ode by Köhnken and Krummen. ${ }^{1}$ The Kleonymidai's lack of success at the Panhellenic games is linked to their great losses in war: they were on the brink of winning, when fortune robbed them of their chance (31-35). Therefore the poet can portray them as winners even though they had not actually won. This is done by turning the Theban festival in honour of Herakles and his eight sons into a simultaneous funeral celebration for

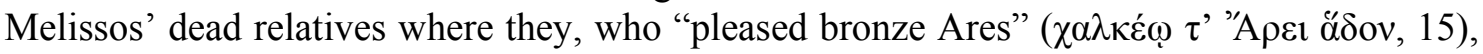
together with the "bronze-clad" ( $\chi \alpha \lambda \kappa o \alpha ́ \rho \alpha \varsigma)$ sons, metaphorically receive winners' crowns ( $\sigma \tau \varepsilon \varphi \alpha \nu \omega ́ \mu \alpha \tau \alpha, 61-66)$.

1. Köhnken (1971:87-116) has as his main aim the interpretation of the function of the Aias myth, while Krummen (1990:33-97) interprets the ode on the basis of the Theban festival for Herakles described in the last antistrophe. Although neither of these authors approaches Isthmian 4 from the perspective of the Kleonymidai's misfortunes, their interpretations seek to explain how their losses at war and in the Panhellenic games are presented in such a way as to be deemed "praiseworthy". The following brief account is based on their readings. 
As for the depiction of Melissos as an ugly victor, Krummen (1990:91, 94-96) is the only scholar who has tried to account for it in some detail. ${ }^{2}$ She comes to the extraordinary conclusion that Melissos was a dwarf and that the passage describing him should actually be read directly as praise. Certainly the exaltation of the victor is the ultimate objective of Isthmian 4, as of all Pindar's other epinikia, but it is achieved in the face of real obstacles which the poet does not shrink from exposing, just as he does not hold back regarding the precarious position from which the Kleonymidai family has emerged thanks to Melissos' victory. It is the aim of this article to show why it is such a challenge to praise an ugly victor and how Pindar rises to the occasion, not only by metaphorically enhancing Melissos' appearance, but also by defending his right to be accepted as a worthy winner.

According to Steiner (1998:126) "athletics was an erotically charged 'spectator sport' which put beautiful bodies on display". In the late sixth and early fifth centuries this appears from the portrayal of athletes in both verbal and visual media, i.e. poetry, vase painting and victory monuments (Steiner 1998:123n2, 124, 142). A closer look at Pindar's epinikia shows that competitors in the combat events especially are singled out as worthy of admiration for their appearance, which makes the unflattering remarks on the physique of a pancratiast such as Melissos all the more exceptional.

If the victors Pindar celebrates are categorised according to their events three main groups may be distinguished: winners in the equestrian events, the combat sports events (boxing, wrestling, pancratium) and the running events (including the mixed event pentathlon). As far as general form and content are concerned - aspects such as mention and praise of the victor, his father and his city, and use of myth and gnomai — there is no apparent distinction on the grounds of this categorisation. However, explicit praise of the physical attributes of an athlete is confined to victors in the combat events, and while the praise of someone's appearance implied in certain images and myths covers a broader range of victors, it too centres on the combat sports victors. ${ }^{3}$

Unequivocal statements of the beauty of the victor are found in six of the sixteen odes dedicated to combat athletes. Aristokleidas, pancratiast of Aigina, is simply called beautiful

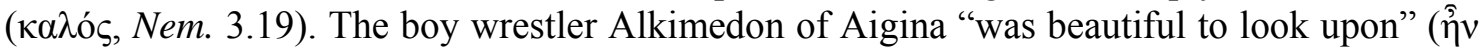
$\delta$ ' $\dot{\sigma} \sigma 0 \rho \hat{\alpha} v \kappa \alpha \lambda$ ó, Ol. 8.19), the wrestler Epharmostos of Opous, winning in the men's class as a youth at Marathon, finds himself admired from all sides for his blooming youthfulness and

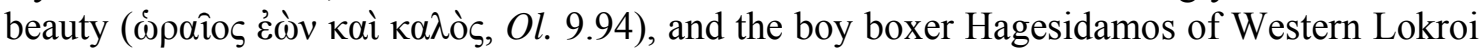

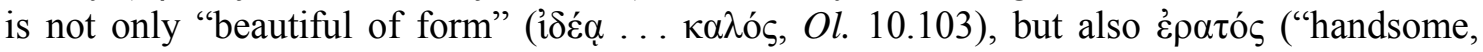
desirable", Ol. 10.99). In addition to their beautiful bodies, the pancratiasts Aristagoras of Tenedos and Strepsiadas of Thebes are noted for their strength. Aristagoras, at his installation

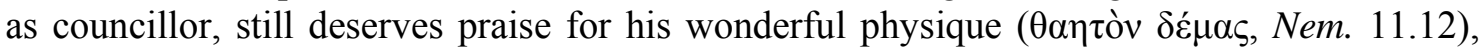

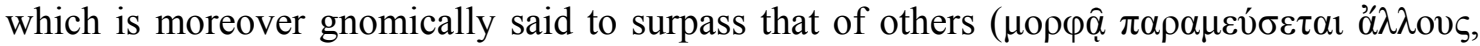
Nem. 11.13), and the ode expresses regret that he never had a chance to display his strength ( $\beta i ́ \alpha$, Nem. 11.22) at the Panhellenic games. Strepsiadas has a powerful impact on the viewer:

2. Willcock (1995:83) suggests humour in the form of a "private joke between poet and victor" as an explanation.

3. See Steiner (1998:136-142) for a discussion of Pindar's presentation of victors as a "source of visual pleasure" (137) comparable to that provided by vase paintings and victory monuments. Although she qualifies the victors singled out for praise of their beauty as mostly adolescents (137), she does not take into account the sporting discipline in which they take part, thus leaving the impression that her analysis applies to victors across the board. In what follows I am indebted to Steiner's insights on the physical radiance with which many victors are endowed by the poet, and the implications of the use of verbs of seeing. 


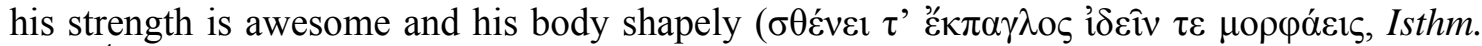

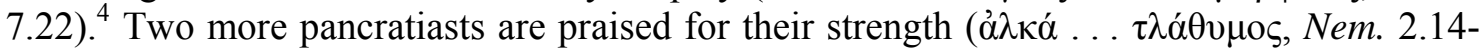

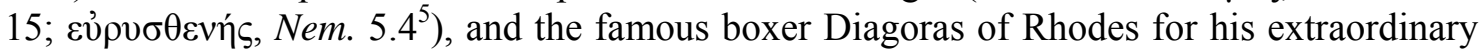
size ( $\pi \varepsilon \lambda \omega ́ \rho ı \varsigma, ~ O l .7 .15)$.

The explicit praise of the appearance of several of these victors is supplemented by imagery which shows them radiating with the lustre of victory, or by associating them with certain deities or mythical figures. ${ }^{6}$ The Muses illuminate the beauty of Strepsiadas ( $\varphi \lambda \varepsilon \dot{\varepsilon} \varepsilon \tau \alpha 1$ $\delta \dot{\varepsilon}$ io $\pi \lambda$ ókoı $\sigma$ Moí $\sigma \alpha 1 \zeta$, Isthm. 7.23), Alkimedon is a "radiant adornment" for his family

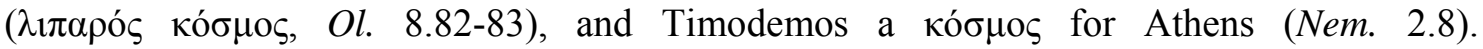
Aristokleidas, a "suitable adornment" for a praise song, is bathed in light from his victories

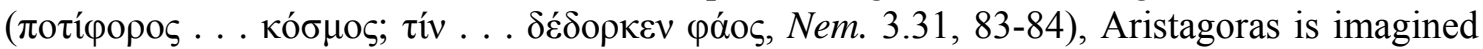

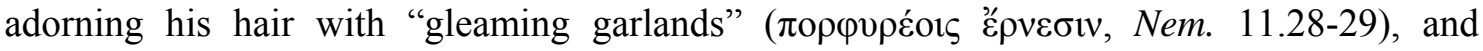
Diagoras, a member of "Herakles' mighty race", is portrayed crowned with blossoms

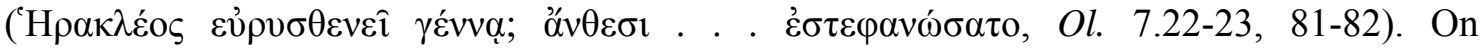

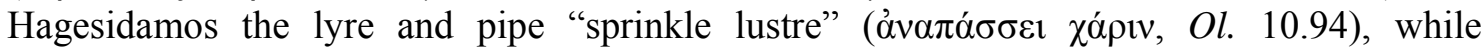
Epharmostos' beauty is foreshadowed by the "indescribably handsome body" of Opous, the

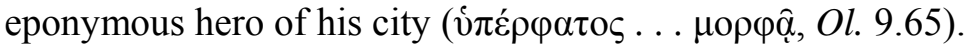

Similar allusions to the pleasing or imposing appearance of the victor can be found in several of the remaining odes for combat events. Like Diagoras, the boy wrestler Timosarchos of Aigina, "splendidly victorious" son of Timokritos, is described as being

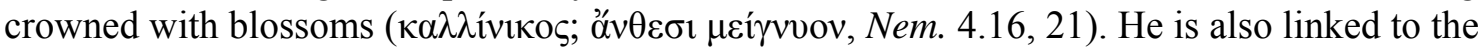
mythical heroes Herakles and "powerful Telamon", who, amongst others, overcame the

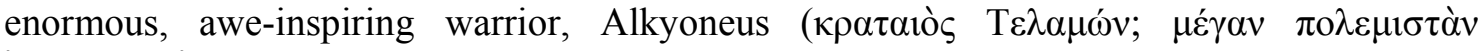

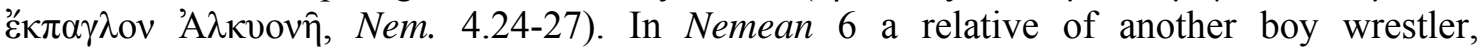
Alkimidas of Aigina, found himself "set ablaze by the loud chorus of the Graces", a description that can be applied to Alkimidas himself, since he has made his "inherited

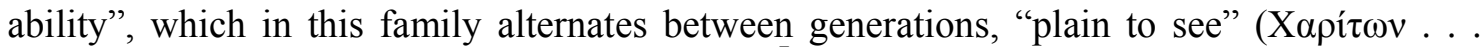

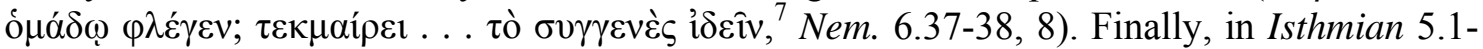
10 , the opening invocation of Theia, Mother of the Sun, and the following gnome paint a picture of the crowned victor, Phylakidas of Aigina, bathed in golden sunlight.

Although none of the runners and pentathletes receives direct praise for his beauty most of the odes in their honour contain references to youthfulness, grace and the charms of love.

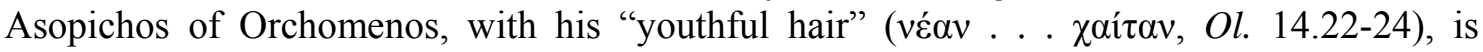
celebrated in a short ode dedicated to the Charites, the source of wisdom, beauty and splendour for mankind (Ol. 14.5-7). Hebe, goddess of youth, and Hora, youthfulness personified, are invoked in the openings of Nemean 7 and 8 respectively, with Aphrodite adding an erotic note to the latter. In Pythian 9 for Telesikrates of Kyrene the erotic element is to the fore throughout, both in the myth of Apollo's pursuit of the nymph Kyrene and in the story of the victor's mythical ancestor Alexidamos' success in winning the daughter of Antaios in a foot race. The desirability reflected on the victor in this way is expressed by the

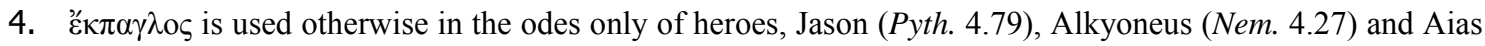
(Isthm. 6.54).

5. See also Isthmian 5.61 for a reference to this victor's dexterity and cleverness.

6. Cf. Steiner (1998:138-140).

7. According to Gerber (1999:51) "the infinitive is explanatory and somewhat superfluous". However, in light of the importance of the internal viewer in many of the odes discussed so far (see below) its deliberate use can be assumed with some confidence. 
internal spectators (of whom more below), women who, seeing him victorious, wish him for a husband or a son (Pyth. 9.97-100). For the boy runner Hippokleas of Thessaly the circle of admirers includes his peers, older men and unmarried girls (Pyth. 10.55-59). In Olympian 13 and Pythian 10 praise of the physical prowess of the victors' fathers is transferred to them by stressing the inherited nature of their own abilities (Ol. 13.13-15, 35; Pyth. 10.12, 22-24).

Victors in the equestrian events rarely drove their chariots themselves, so that youth and physical prowess were not significant for success. It is therefore not surprising that few of the odes celebrating them mention either beauty or youthfulness, although on these victors too success is said to shed a beautifying light, as appears from a gnome on the envy aroused by "those who ever drive first around the twelve-lap course and on whom revered Charis sheds a

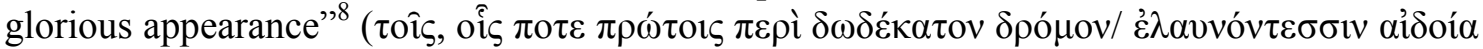

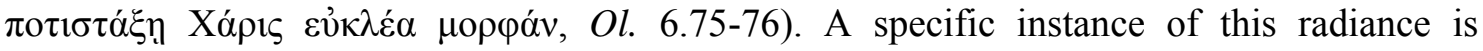
Xenokrates of Akragas. His Isthmian victory makes him a "light" ( $\varphi \alpha ́ o \zeta)$ among his fellow

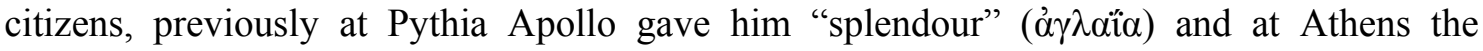
Charites, graceful favours, of the sons of Erechtheus, attended him (Isthm. 2.12-20). In Pythian 5 the lustre of victory is not attached to the chariot owner, Arkesilas of Kyrene, but to his charioteer, Karrhotos, whom the "lovely-haired Graces are setting ablaze" (†ंv́коно

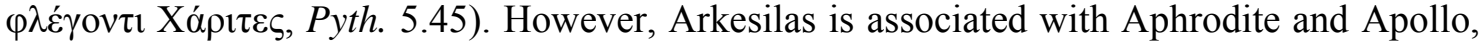
and is praised for standing strong in competition (Pyth. 5.24, 103-104, 113) - he and his charioteer make an impressive pair. That a charioteer could be as imposing as any other athlete, appears from the comparison of the only owner-charioteer, Herodotos of Thebes, with Kastor and Iolaos, the "most powerful charioteers among the heroes" (í $\rho \omega \omega v$

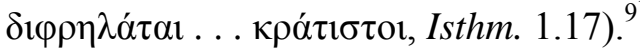

The options open to the poet regarding praise of a victor's appearance may now be summarised as follows:

- The victor's appearance is not mentioned. This applies to most equestrian victors, but the group also includes a few runners and combat athletes.

- Deities and personifications such as Aphrodite, Apollo, Hebe, the Charites and Hora are used to paint a picture of youthfulness, grace and erotic allure. It is mostly runners and combat athletes who are depicted in this way.

- The victor is depicted as bathed in or giving off light. Victors in all disciplines show this "halo effect", but proportionally more combat athletes are treated in this way.

- Explicit references are made to the beauty, size or strength of the athlete, often in combination with one or both of the two previous options. These statements are confined to combat athletes. ${ }^{10}$

Although appearance features with regard to 13 of the 16 combat event victors celebrated by Pindar, ${ }^{11}$ it is clear from the above that for those who perhaps do not merit an accolade like $\kappa a \lambda$ ós, there are other more subtle means available to portray them as handsome and

8. Translation Race (1997a). The envy seems to be not only on account of the victory itself, but also the fact that it enhances the victor in the eyes of others.

9. For a discussion of the sensual appeal of a charioteer depicted on a victory monument, see Steiner (1998:135-137).

10. Herodotos' strength is implied in a comparison (see discussion of equestrian victors above), while chariot race winner Chromios of Aitna's prowess in battle is alluded to in two gnomai (Nem. 3.26-28, Nem. 9.3742).

11. No reference is made to the appearance of Aristomenes of Aigina (Pyth. 8), Theaios of Argos (Nem. 10) and Kleandros of Aigina (Isthm. 8), although the latter's youth ( $\dot{\alpha} \lambda \iota \kappa i ́ \alpha)$ is mentioned in the opening line. 
desirable, or the subject can be avoided. ${ }^{12}$ This raises the question: why did Pindar go so far as making negative comments on the appearance of one athlete? Why not pass over this detail and concentrate on his success in the games, which has provided plenty of material for praise? Why not stop at the techniques of idealisation which, as will be shown, are in fact applied to Melissos? ${ }^{13}$

A closer look at how Melissos' appearance is presented in Isthmian 4 will provide some clues as to the answer to these questions.

The first statement, "for he was not allotted the bodily nature of Orion" (oủ yà $\rho$ pv́бıv ' $\Omega \alpha \rho \omega v \varepsilon i ́ \alpha v$ ' $2 \lambda \alpha \chi \varepsilon v$, Isthm. 4.49) can be read as an explanation of why Melissos needed the special skills and tactics described in the previous lines to overcome his opponents. The negative comparison with the giant Orion points to his shortness, a disadvantage in the combat sports, which were "the domain of the large and strong" (Poliakoff 1987:8). ${ }^{14}$ However, Orion was famous not only for his size, but also for his handsomeness, ${ }^{15}$ a feature Melissos clearly does not share. This statement is thus already an indirect indication that what he has been granted (" $\varepsilon \alpha \alpha \chi \varepsilon v)$ as far as suitability for a combat event is concerned, is not the prized inherited nature regularly praised in other athletes. ${ }^{16}$

The suggestion that Melissos is ugly is confirmed by the blunt observation that he was óvo ós to look at (Isthm. 4.50). Although the meaning "to be blamed or scorned, contemptible" (LSJ, s.v.) seems obvious, considering its derivation from ôvo $\mu \alpha$, "to blame, find fault with, treat scornfully, throw a slur upon" (LSJ, s.v.), most commentators and translators appear to find it too strong, preferring renderings such as "paltry" (Race 1997b:169), “unansehnlich”(Dönt 1986:257), “äußere Unscheinbarkeit” (Köhnken 1971:94), "unimpressive" (Willcock 1995:83) and "ill-favoured" (Bury 1892:73). ${ }^{17}$ These renderings make of óvotós mainly an indication of someone's appearance, and underplay the fact that it also, perhaps even primarily, points to a negative attitude towards the person observed on the part of the onlookers. ${ }^{18}$ The rarity of the word in the extant literature does make it difficult to

12. Praise for the form or beauty of boxers was rare on victory monuments, as "boxing was disfiguring" (Poliakoff 1987:10). He also notes the absence of the title atraumatistos ("unwounded") for boxers (165n9), presumably because an ugly appearance was silently passed over rather than commented on. The portrayal of an ugly boxer on a vase is regarded as an exception to the rule of showing only "lithe and slender" figures (Bonfante 1989:555-556).

13. On idealisation and "youthening" in the portrayal of victors, see Steiner (1998:132-133).

14. Contra Krummen (1990:91) who interprets his small physique as ideal for the pancratium.

15. Orion was a hunter and a giant, the son of Poseidon. In the Odyssey Otus and Ephialtes, at nine years already "nine cubits in breadth and in height nine fathoms", are described as the "tallest, and far the most handsome, after famous Orion" (Od. 11:305-312). Odysseus also refers to his huge size when he sees him in the underworld (Od. 11:572). There may even be a hint at lack of sexual prowess in the negative comparison with Orion. Cf. Griffiths (1986:66-67) on the hero's "irrepressible randiness". On the various elements of the Orion myth, cf. Fontenrose (1981:esp. 5-32).

16. Some examples are Olympian 8.15-16, Olympian 13.13, Pythian 8.35-45, Pythian 10.12, Nemean 6.8-16. Note that in the praise for Melissos' chariot victory, he is credited with not disgracing his inherited

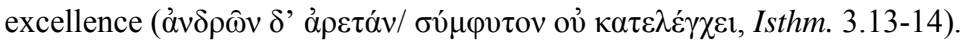

17. Bury does give "contemptible" in his line by line commentary, but softens it to "ill-favoured" in the translation of the whole passage preceding the commentary. In his commentary on these lines Thummer (1969:76) ignores this reference to Melissos' appearance.

18. Dover (1974:72) describes this distinction with reference to actions as follows: "Clearly we can qualify an act either by an epithet suggesting how one reacts to it or by an epithet denoting the attribute by virtue of which one has that reaction". I contend that óvotós denotes the former, with the comparison with Orion playing the role of the latter. 
assess its impact, but the four instances besides Pindar cited in LSJ all centre on the element of scorn or contempt. One example will suffice. In Apollonios Rhodios' Argonautica Medea says to Jason and the other Argonauts after having fled her home to join them on their return

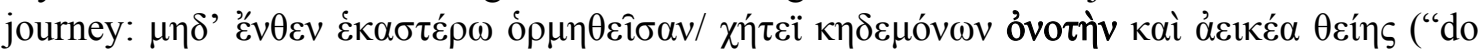
not make me, now that I have fled far away from there, scorned and dishonoured for want of protectors", 4.90-91). ${ }^{19}$

That ỏvotós is meant to convey the attitude of observers is confirmed by its use in conjunction with i $\delta \varepsilon \dot{\sigma} \sigma \alpha$ l, "to see". Positing an internal viewer through whose eyes the audience of the poem is invited to look at someone in a particular way, is a well-established technique in Greek literature. ${ }^{20}$ As far as Pindar is concerned, Steiner suggests two related functions for this technique. On the one hand it "marks the athlete's perfect physique as an object of display" (Steiner 1998:137), on the other hand it mediates the onlookers" "erotic longings, and desire to possess (the athlete) in all his loveliness" (Steiner 1998:140). ${ }^{21}$ Clearly neither of these functions applies to Melissos. While beauty attracts admiration, the implication is that Melissos' appearance has given rise to scorn. For example, in the Homeric epics, epithets on the beauty and strength of both Greek and Trojan warriors are common. The notable exception is Thersites:

He was the ugliest man there at Troy:

bandy-legged, lame in one foot, with shoulders

hunched over his chest - and above all this,

a pointed head with some scraggly hair. (Il. 2.216-219; trans. Reck 1994.)

He was certainly no hero, and his ugly physique can be seen as a mirror of his contemptible nature. He is always trying to ingratiate himself with the other warriors by bad-mouthing the commanders, but this costs him a strong reprimand and a beating from Odysseus and earns him no respect from his more subservient fellows.

That Melissos' victory would have seemed incompatible with his appearance is confirmed by two Pindaric passages in which a victor's beauty and his deeds are directly linked. The boy wrestler Alkimedon "was beautiful to look at, and with his efforts did not dishonour his

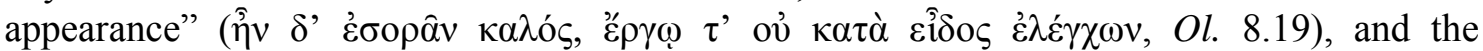
pancratiast Aristokleidas is described as "being beautiful and performing (deeds) fitting his

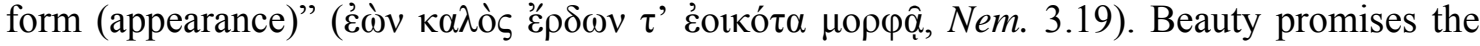
ability to perform, and great deeds fulfil this promise. The opposite, ỏvo ós implies, can provoke scorn even in the face of achievement. ${ }^{22}$

To return to the question of Pindar's negative comments about Melissos' appearance: I propose that by conceding, instead of passing over, his physical shortcomings, Pindar indicates that an important object of the poem is to defend Melissos' claim to be

19. The other instances of the word are Hom. Iliad 9.164 (gifts to Achilles not to be despised), Callim. Hymn 4.19-20a (Cyrnus is no mean island) and ps-Lycoph. 1235 (Aeneas not to be despised in battle).

20. Cf. Hom. Hymn Apollo 198, Hom. Hymn Pan 36, victory statue epigram Ebert 12 = Anth. Pal. 16.2 (dated to the first half of the fifth century, also known as Simon. epigram XXX), Xen. Symp. 1.8-10. On the role of the gaze in vase painting, see Frontisi-Ducroux (1996).

21. Examples of the former are Olympian 8.19, Isthmian 7.22, and of the latter Olympian 10.99-105, Olympian 9.89-98, Pythian 9.97-100, fr. 123.2-6, 10-12. Cf. also Nemean 6.8 (inherited ability plain to see) and Isthmian 2.18 (Apollo sees the victor and adds to his lustre).

22. Cf. Carey's remarks on the link between appearance and excellence (Carey 1976:26). 
acknowledged a worthy winner against those who would have it otherwise. ${ }^{23}$ This thesis is supported by the myths Pindar uses, as well as the ways, direct and indirect, in which he portrays Melissos and the strong emphasis he places on both heroes' and humans' deeds.

Central to this interpretation is Pindar's treatment of the myth of Aias' suicide, placed at the exact centre of the poem, between praise of the family and praise of Melissos. ${ }^{24}$ The myth is introduced as an illustration of the gnomic comment that a weaker man can overcome a stronger through skill (Isthm. 4.34-35). Aias committed suicide after the Greeks voted to give Achilles' armour to Odysseus instead of to him: he was undone by the craft of $\pi \mathrm{o} \lambda \hat{\mu} \mu \eta \tau 1 \varsigma$ Odysseus ("of many wiles"). However, Pindar underplays Odysseus' role in this incident he is not even mentioned and there is nothing of the strong anti-Odysseus sentiment evident in his portrayal of these events in Nemean 7.20-33 and Nemean 8.20-34. The focus is

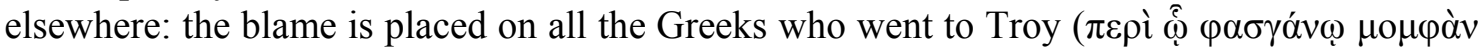

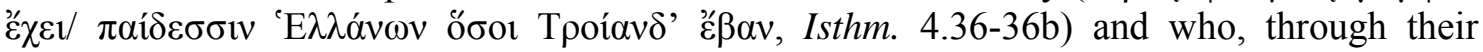
choice, refused to acknowledge Aias as the strongest and handsomest warrior after Achilles (Il. 17:279-280). In contrast, Homer did for Aias with his poetry what the Greeks would not do. $\mathrm{He}$

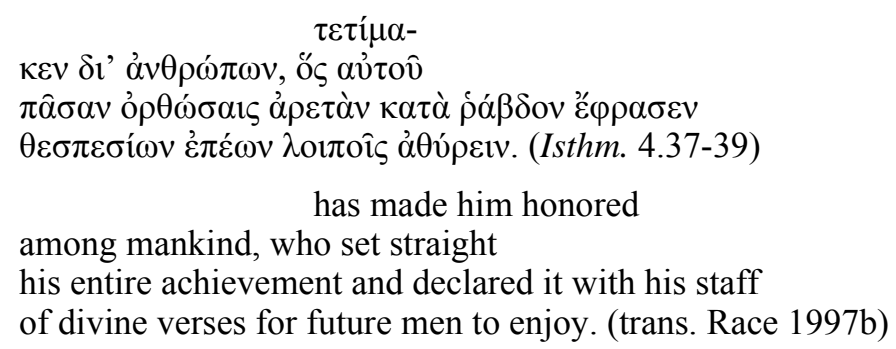

Through Homer the Greeks' bad judgement was reversed, Aias was redeemed and his deeds were made known to posterity. Thus Pindar uses the myth to demonstrate the extraordinary power of poetry. It can set the record straight and confer immortality. "If someone says it

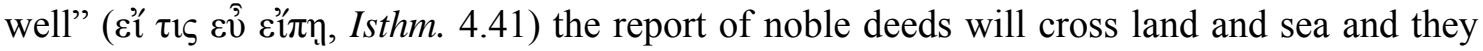
will acquire a radiance that can never be dimmed, they will become an inextinguishable light (Isthm. 4.41-42).

The part of the poem which precedes the Aias-Homer myth is devoted to praise of the deeds of Melissos' family. Like Aias, the Kleonymidai have suffered reversals of fortune, and Pindar makes it clear that his poetry has the power to restore them to their former glory. Poseidon, patron god of the Isthmian games,

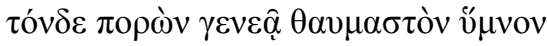

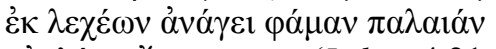

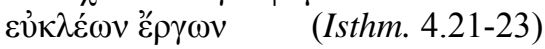

by granting this marvelous hymn to the clan is rousing from its bed their ancient fame for glorious deeds (trans. Race 1997b)

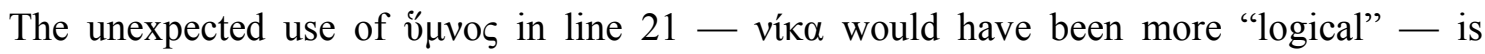
significant. Without Melissos' victory there would have been no hymn and in that sense the

23. Parallels can be drawn between this undertaking and efforts to ward off the envy that success attracts. Cf. Willcock (1982:9) on envy as a Hindernismotiv, i.e. one of the "imaginary difficulties set up by the poet to make his praise more valuable and convincing".

24. For a detailed analysis of Pindar's treatment of the Aias myth in this ode, see Köhnken (1971:104-114). 
victory is the basis of the restoration of the family's fame. However, by letting the song stand for the victory here, Pindar claims the real redemptive power for his poetry, which makes the achievement known. It is through the poetry accompanying Melissos' victory that his family's fame is revived.

As has been shown, this power of poetry, as well as the immortality it bestows, is evoked quite explicitly in the Aias-Homer myth, which can then be read as a reinforcement of the idea that the present poem will re-establish the family's tarnished fame. However, the main force of the myth is found in its application to Melissos. It forms a bridge from praise of the family to the second part of the poem which is devoted to Melissos. This section of the poem starts with an unequivocal statement of what the poet hopes to achieve, namely "to light such

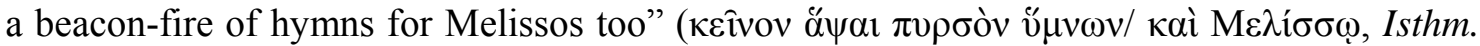
4.43-44 - note the emphatic use of kai at the beginning of the verse). Thus a direct line is drawn from Homer and Aias to Pindar and Melissos. Homer's poetry has set the record straight on the whole of Aias' achievements, which, it is implied, had been blighted by the events surrounding his suicide. In this way he has safeguarded Aias' honour among mankind and has ensured the immortality of his deeds. Pindar has already implied that his poetry will restore the family's fame. Now he states his aim as celebrating Melissos' achievements in such a way that he will receive the honour and immortality he deserves. ${ }^{25}$

Significantly, Pindar includes the audience, among them presumably those who found Melissos óvotós to look at, in this key passage of the poem. The Aias-Homer myth is

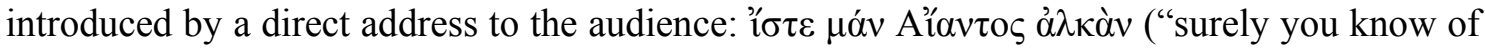
Aias' . . valour", Isthm. 4.35-35b), and when the subject thus raised is rounded off with the application of the myth to Melissos, the request for the Muses' assistance is made in the first

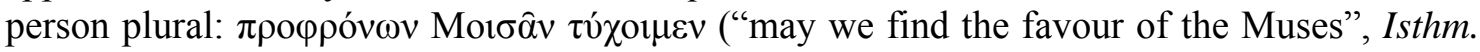
4.43). By including the audience so pointedly in this passage, it is implied that the blame attached to the Greeks for disrespecting Aias will also adhere to the audience if they do not acknowledge Melissos. However, it also makes them co-responsible for and provides them with an opportunity of praising Melissos properly.

In the course of praising the family Pindar has in fact already lighted the $\pi v \rho \sigma o ́ v$, the "beacon-fire", for Melissos through his choice of images to celebrate their return to prominence and fame. Viewed in the light of Melissos' unimposing appearance, these images are especially instructive.

His victory is likened to the arrival of spring after the darkness of a harsh winter. ${ }^{26}$ Spring

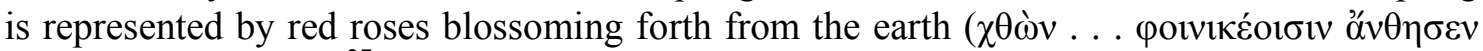
podors, Isthm. 4.18b). ${ }^{27}$ The lushness of the flowers attests to the vigour imparted by success, and the image may be compared to a similar one used of Arkesilas' success in Pythian 4 to show that the Battidai are still flourishing after eight generations of rule in Kyrene: ఝँ $\tau \varepsilon$

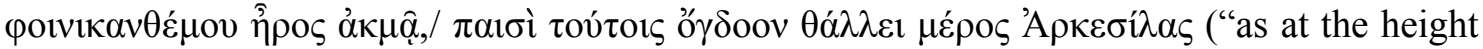
of red-flowered spring,/ the eighth generation of those sons flourishes in Arkesilas", Pyth. 4.64-65; trans. Race 1997a). The vigour of success made visible in the roses also points to the

25. Cf. Pythian 10.55-59. Here the poet also expresses the hope that his songs will enhance the standing of the athlete. However, the circumstances are rather more favourable - he need not establish the victor's worth,

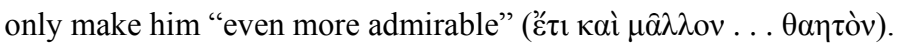

26. For a detailed discussion of the winter imagery, see Krummen (1990:80-81).

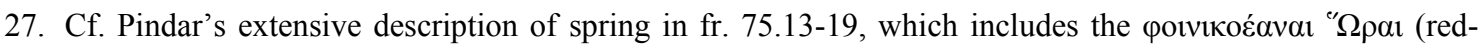
robed Horai) and roses. 
triumph of life over death which Melissos' victory means for a family reeling under the simultaneous loss of four men. ${ }^{28}$ The red roses are a striking metaphor for vitality and beauty, qualities thus indirectly attributed to Melissos. ${ }^{29}$

The second image is even more lustrous and explicit. By granting the victory at the Isthmos Poseidon has roused the ancient fame of the Kleonymidai from its sleep ( $\dot{\varepsilon} \kappa \lambda \varepsilon \chi \dot{\varepsilon} \omega v$

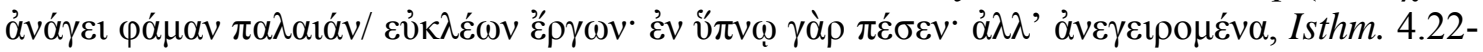
23), and now "its body shines, splendid like the Morning Star among the other stars" ( $\chi \rho \hat{\omega} \tau \alpha$

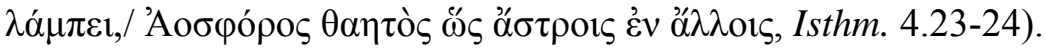

The family's fame, which is compared to the Morning Star, can again take its prominent place in the community. From being hidden in a bedchamber it has moved to a place where it is clear for everyone to see in all its splendour. It is significant that the family's fame is given a concrete form by the use of $\chi \rho \omega ́ s$ - the simile would have worked equally well without it. And no one but Melissos can be that body. In the introduction to the poem Melissos is proclaimed as the source for the current praise of the family, having amply displayed his

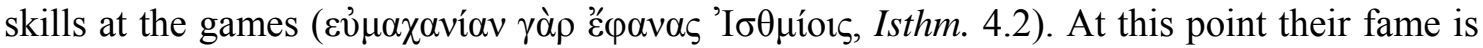
literally embodied in him and he is as bright as the Morning Star. Through his victory he has outshone the other competitors, and, as their first Panhellennic victor, has also become the foremost athlete in his family. The luminosity associated with successful athletes, ${ }^{30}$ already hinted at in the images of spring, is now fully expressed. The significance of the image of the Morning Star for the perception of Melissos as a worthy winner, becomes clear from Bacchylides Ode 9.27-31, where a similar image is connected explicitly with the victor's imposing appearance. Automedon is said to be "conspicious among the pentathletes, as the bright moon outshines the light of the stars in the midmonth night: even so in the immense circle of the Greeks did he display his wonderful form ...", his $\theta \alpha v \mu[\alpha] \sigma \tau o ̀ v ~ \delta \varepsilon ́ \mu \alpha \varsigma$ (trans. Campbell 1992:163). ${ }^{31}$

The images of red roses and the Morning Star not only make the splendour of the family's new fame visible but also metaphorically endow Melissos with striking physical qualities. When, in the second half of the poem, Pindar moves to direct praise of the victor he focuses on his actions and the inner qualities they reveal. To achieve this he uses two animal images and the mythical figure of Herakles.

In contest Melissos is likened to the lion and the fox:

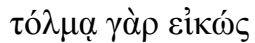

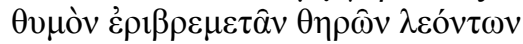

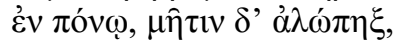

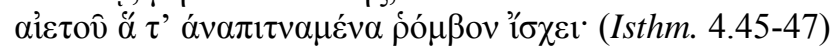

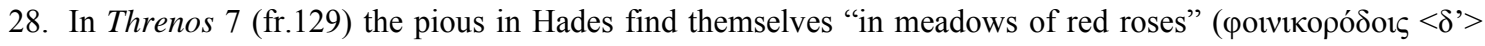
$\lambda \varepsilon \iota \mu \omega ́ v \varepsilon \sigma \sigma 1)$. See Segal (1981:84n13) for more examples of roses symbolising victory over death.

29. For the use of roses in an erotic context, see Bacchylides 17.109-129. Theseus receives from his mother

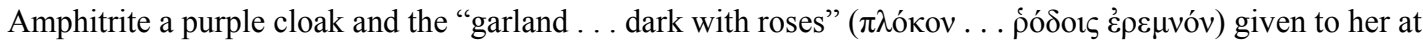
her marriage by Aphrodite. Back at his ship his splendid appearance ("the gods' gifts shone on his limbs",

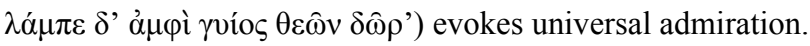

30. See analysis above of the ways in which victors' appearance is presented.

31. Note too how Bacchylides' description of Automedon illustrates Steiner's statement that "(b)oth visual and verbal media exhibit youthful bodies at their prime that glisten, gleam, and combine strength with sexuality and erotic allure. Artists and poets both explicitly or implicitly surround their pictures of fleeting loveliness with viewers who gaze admiringly on the scene" (Steiner 1998:142). 
For in spirit he resembles

the courage of loudly roaring wild lions

during the struggle, and in craft he is a fox,

which falls on its back and checks the eagle's swoop.

With these images Pindar ascribes a range of qualities to Melissos. His spirit is daring and courageous (the $\tau$ ó $\lambda \mu \alpha$ of the lion), but he is also aggressive and ferocious (the loud roar and wildness of the lion). Yet there is more to his effort than brute force. He possesses the wiliness of the fox and knows how to thwart the attacks of his opponents. ${ }^{32}$ The gnomic comment which follows, "one must do everything to weaken (obscure) one's adversary" ( $\chi \rho \eta$

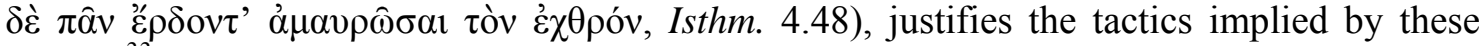
images. ${ }^{33}$ The tactics and the comment are in turn explained by the description of Melissos' unimposing physique.

The myth that flows from this description has Herakles as its theme (Isthm. 4.52-66). Pindar leaves no room for doubt that he wishes to make a direct connection between Melissos and the hero: Herakles set out from his and Melissos' home town, Thebes, to wrestle with the barbaric giant Antaios. He used not only his strength, but also his cleverness to outwit Antaios, as Pindar has implied Melissos did to overcome his opponents - as soon as Herakles realised that Antaios gained strength from being thrown on the earth, his mother, he held him in the air and throttled him. Pindar even goes as far as linking them physically, by

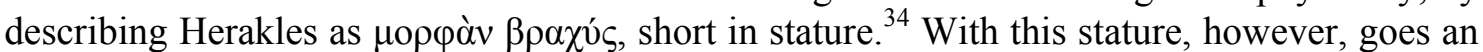
unflinching spirit that will not bend or give in, Herakles is $\psi v \chi \alpha \alpha^{\prime} v \alpha^{\prime} \kappa \alpha \mu \pi \tau$ (5) (53b). It is this spirit, to which the lion image has already alluded, which is at the heart of both Herakles' and Melissos' success.

The rest of the myth refers briefly to Herakles' exploits on land and sea (55b-57), and the reward of immortality he received for his achievements (55a, 58-60). Moving back to the human sphere, Pindar describes the festival in Herakles' honour held by the citizens of his birthplace (61-66). Thus the myth exemplifies the twin aims of the poem already stated in the Aias-Homer myth, namely achieving for Melissos the honour of his fellow citizens, and immortality. Here, as in the Aias myth, the audience is directly involved in the implied praise

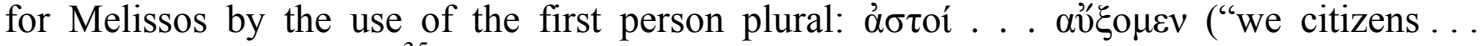
honour", Isthm. 4.62-63). ${ }^{35}$

In both myths the hero's reward of honour and eternal fame is grounded in his deeds. They demonstrate that on the strength of Melissos' deeds, i.e. his victories in the local and especially the Panhellenic games, he deserves the praise of his fellow citizens as well as immortality through great poetry, ${ }^{36}$ not the scorn implied in the description of his physique.

32. On the wiliness of the fox, see Detienne and Vernant (1978:34-37) and, for an explanation of the technique involved Krummen (1990:90, with notes 38 and 39), and Willcock (1995:82).

33. On helping friends and harming enemies, cf. Pythian 2.83-85 and see Dover (1974:180-184) and Blundell (1989, esp. 26-59).

34. Most commentators find this description of Herakles a "surprise" (Willcock 1995:84). Thummer (1969:7677) speculates that it may stem from comedy. An indication that a relatively small Herakles was perhaps not completely unusual is his depiction on a vase by the Niobid Painter from the middle of the fifth century which probably refers to an earlier wall-painting (Osborne 1998:164-167). Osborne describes the figure in the foreground of the vase painting as "a giant compared to the stocky Herakles above him" (Osborne 1998:164; my emphasis).

35. On the interpretation of $\alpha$ ' $\xi o \mu \varepsilon v$, see Krummen (1990:42-43, 54).

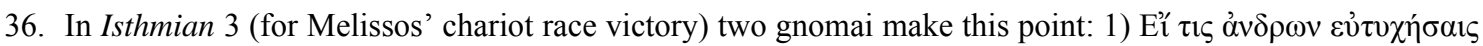

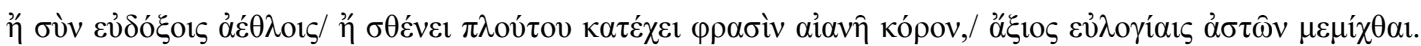


In fact, the pre-eminence of his deeds is precisely what Pindar emphasizes even as he admits the deficiencies of Melissos' appearance.

The $\dot{\alpha} \lambda \lambda \alpha \alpha^{\prime} \ldots \mu \varepsilon^{\prime} v \ldots \delta \dot{\varepsilon}$ construction used in the description of Melissos signals that the statement about Melissos' strength in hand-to-hand fighting counters both previous ones

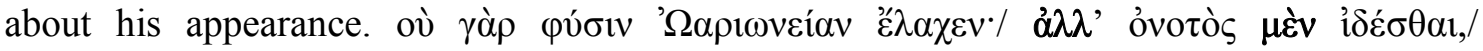
$\sigma v \mu \pi \varepsilon \sigma \varepsilon \hat{i} v \delta$ ' $\alpha \kappa \mu \alpha \hat{\alpha} \beta \alpha \rho v ́ \varsigma$ (Isthm. 4.49-51) can be rendered "he was not allotted the bodily nature of Orion, but he is heavy to grapple with in his strength" and "although he is contemptible to look at, he is heavy to grapple with in his strength". The chiastic structure of lines 50 and 51 heightens the contrast between $\sigma v \mu \pi \varepsilon \sigma \varepsilon i v$ and i $\delta \varepsilon \dot{\varepsilon} \sigma \theta \alpha 1$, and emphasises the former. This is especially significant considering the usual force of verbs of looking in the context of an athlete's appearance, and underlines that to look at Melissos is one thing, to meet him in the close encounter of the pancratium something quite different. Melissos' power

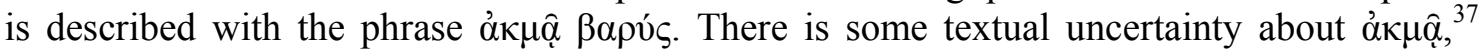
which could mean "in his strength" or, perhaps, "in his prime". For ßapú made between the literal meaning "heavy in weight", in Homer mostly with the collateral notion of "strength and force" (LSJ, s.v.), and the metaphorical sense "heavy to bear, grievous" (LSJ, s.v.). The former would enhance the notion of Melissos' strength in combat, and might at the same time be an oblique reference to a heavy body. Other occurrences of the word in the epinikia favour the metaphorical sense, ${ }^{38}$ in which case the word would apply more to Melissos' effect on opponents in fighting, that it was grievous for them to encounter him. But whether his strength, or even weight, or his effect on others predominates, the point is made that he is superior in combat, regardless of his looks.

Melissos' success challenges the conventional notion of a connection between beauty and deeds. The closeness of this connection is quite evident in the odes in which explicit reference is made to the beauty of the victor. The idea that beauty signifies ability which is confirmed by deeds has already been noted regarding Alkimedon and Aristokleidas (Ol. 8.19, Nem. 3.19, p. 48). Admiration for the strength and beauty of Strepsiadas is followed by the

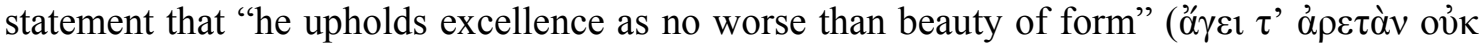

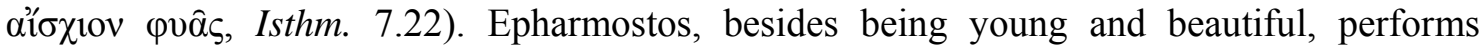

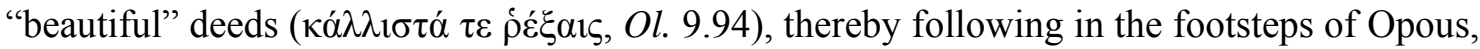
his city's hero, who is famous for both his handsome body and his deeds (Ol. 9.65-66).

In Isthmian 4 Pindar responds to the "beauty equals great deeds" convention by transforming the related idea, that deeds show the real worth of the beautiful man. Valuing deeds in this way appears from two negative examples in the Iliad. Hektor is contemptuous of Paris who is all beauty and no action (Il. 3.1-57). When Hektor sees him shrink back from Menelaus he reacts scathingly: while Paris' extraordinary beauty — the narrator has already used the epithet $\theta \varepsilon 0 \varepsilon 1 \delta \eta \dot{~(" g o d l i k e ~ i n ~ f o r m ") ~ f o u r ~ t i m e s ~ i n ~ t h i s ~ s c e n e ~ a n d ~ H e k t o r ~ c a l l s ~ h i m ~}$

(1-3; "If a man is successful, either in glorious games or with mighty wealth, and keeps down nagging excess in his mind, he deserves to be included in his townsmen's praises". Trans. Race 1997b.) 2) $\varepsilon v 3 \kappa \lambda \varepsilon \dot{\varepsilon} \omega v$

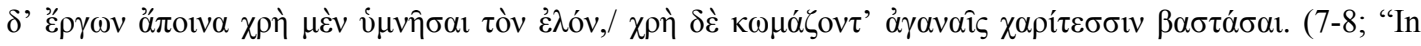
recompense for glorious deeds one must hymn the good man and must exalt him, as he revels, with gentle poems of praise". Trans. Race 1997b.)

37. See Thummer (1969:76).

38. Ol. 2.23, Pyth.1.75, Pyth. 3.42, Pyth. 5.63, Nem. 10.20. In Nemean 6.50-51, about Achilles' defeat of the Ethiopians, the diction, including the ambiguity of meaning, is remarkably similar to that of the passage on

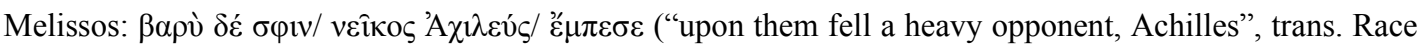
1997b). 


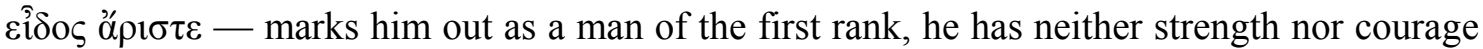

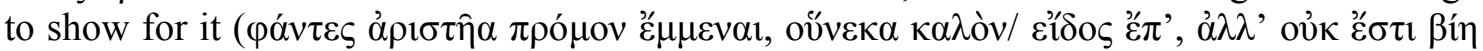

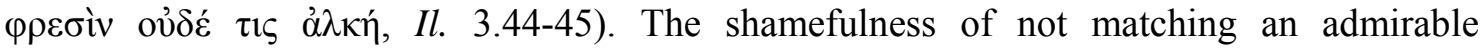
appearance with admirable deeds is also clear in the formulaic reproach uttered by Hera (Il. 5.787) and Agamemnon (Il. 8.228) when the Greeks waver in the face of Trojan attack:

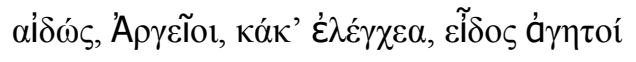

Shame, Argives, base things of dishonour, admirable in appearance only!

What Pindar does in the case of Melissos, is to break the link between beauty and deeds and present deeds alone as sufficient for earning grace, a form of beauty, and immortality. For Pindar deeds speak louder than looks. Deeds show the worth of a man, regardless of his appearance. Therefore he can compose a poem that not only holds out the promise of fame in times to come but can also, in the here and now, transcend the victor's physical limitations. His deeds make him worthy of being likened to red roses and the Morning Star, and as a final tribute, just as the "lyre and ... pipe shed grace" on the beautiful Hagesidamos of Western

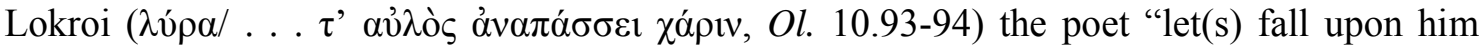

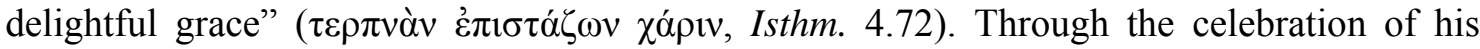
deeds in poetry Melissos is transformed from a man "contemptible to look at" to one covered in grace. By ending his poem on this image, Pindar challenges his audience to look past the victor's appearance and give him the honour he deserves as a man of action.

\section{BIBLIOGRAPHY}

Blundell, M W 1989. Helping friends and harming enemies: A case study in Sophocles and Greek ethics. Cambridge: Cambridge University Press.

Bonfante, L 1989. Nudity as costume in classical art. AJA 93:543-70.

Bury, J 1892. The Isthmian odes of Pindar. London: Macmillan.

Campbell, D A (ed. and trans.) 1992. Greek lyric IV: Bacchylides, Corinna, and others. Loeb Classical Library 461. Cambridge, Mass.: Harvard University Press.

Carey, C 1976. Pindar's eighth Nemean ode. PCPS 22 (ns):26-41.

Detienne, M \& Vernant, J-P 1978. Cunning intelligence in Greek culture and society (translated by Lloyd, J). Sussex: Harvester Press.

Dover, K 1974. Greek popular morality in the time of Plato and Aristotle. Oxford: Basil Blackwell.

Dönt, E (ed. and trans.) 1986. Pindar: Oden. Stuttgart: Reclam.

Fontenrose, J 1981. Orion: The myth of the hunter and the huntress. University of California Publications in Classical Studies 23. Berkeley; Los Angeles: University of California Press.

Frontisi-Ducroux, F 1996. Eros, desire, and the gaze (translated by Kline, N). In Kampen, N B (ed.), Sexuality in ancient art: Near East, Egypt, Greece, and Italy, 81-100. Cambridge: Cambridge University Press.

Gerber, D E 1999. Pindar, Nemean six: A commentary. HSP 99:33-91.

Griffiths, A 1986. "What leaf-fringed legend ...?" A cup by the Sotades painter in London. JHS 106:58-70.

Köhnken, A 1971. Die Funktion des Mythos bei Pindar. Untersuchungen zur antiken Literatur und Geschichte 12. Berlin: Walter de Gruyter.

Krummen, E 1990. Pyrsos Hymnon: Festliche Gegenwart und mythisch-rituelle Tradition als Voraussetzung einer Pindarinterpretation (Isthmie 4, Pythie 5, Olympie 1 und 3). Untersuchungen zur antiken Literatur und Geschichte 35. Berlin: Walter de Gruyter.

Osborne, R 1998. Archaic and Classical Greek art. Oxford: Oxford University Press.

Poliakoff, M 1987. Combat sports in the ancient world: Competition, violence, and culture. New Haven, Conn.: Yale University Press. 
Race, W H (ed. and trans.) 1997a. Pindar I. Loeb Classical Library 56. Cambridge, Mass.: Harvard University Press.

Race, W H (ed. and trans.) 1997b. Pindar II. Loeb Classical Library 485. Cambridge, Mass.: Harvard University Press.

Reck, M (trans.) 1994. Homer: The Iliad. New York: HarperCollins.

Segal, C 1981. Myth, cult, and memory in Pindar's third and fourth Isthmian odes. Ramus 10:69-86.

Steiner, D T 1998. Moving images: Fifth-century victory monuments and the athlete's allure. ClAnt 17:123-53.

Thummer, E 1969. Pindar: Die Isthmischen Gedichte II. Heidelberg: Carl Winter.

Willcock, M 1982. Second reading of Pindar: The Fourth Nemean. G \& R ser. 2, 29:1-10.

Willcock, M (ed.) 1995. Pindar. Victory odes: Olympians 2, 7, 11; Nemean 4; Isthmians 3, $4,7$. Cambridge Greek and Latin Classics. Cambridge: Cambridge University Press. 